\title{
Stories from No Land: The Women of Srebrenica Speak Out
}

\author{
Selma Leydesdorff
}

\begin{abstract}
It is argued that the stories of the survivors of the Srebrenica massacre in 1995 have been neglected by the memorial culture of Bosnia and by the various national reports that investigated how the massacre could have taken place. The author argues that a satisfactory history of the genocide has to include the voices of the survivors, in this case, the women. These are stories of trauma that are hard to listen to. She compares listening to them to the difficulty historians experience in listening to the stories of other genocides like the Shoah/Holocaust, they are stories based on silence about what cannot be told. The argument relies on the oral history literature on listening to trauma as personal and subjective accounts of survival. They are not straightforward referential narratives. One narrative, the narrative of Sabaheta who lost her child and husband, is central to the piece. She is one of the women interviewed by the author. The interview expresses sorrow about loss and rage about the international community; these stories are interwoven. The narrative also describes through the eyes of the victim what she felt happened. The author is Dutch, so is part of the one nation - more than any other - that is accused of "doing nothing." It was the Dutch army that was supposed to protect the civilian population of Srebrenica. The government of The Netherlands has halted any negotiation on financial support for the research as "the project does not help to overcome trauma." She argues that giving a voice to the victim is a necessary step toward closure.
\end{abstract}

\section{Background}

During the war in Bosnia, so-called "safe areas" were created territories protected by the United Nations (UN) where Muslims could take refuge from "ethnic cleansing" (Rhode 1997; Cecik et al. 2001; De Barros-Duchene 1997; Honig and Both 1996; Silber and Little 1997). One of these safe areas was Srebrenica, which was protected by the Dutch Army under the UN command until it fell into Serbian hands. The Serbs conquered the enclave in July 1995 and massacred thousands of civilians. Exactly how many were murdered is unknown, but the reported figures range between 7,000 and 10,000. Before the massacre began, women, children, and older men were herded into the UN compound of Potocari, where they expected shelter. Many younger men had chosen to risk fleeing through the woods to a territory controlled by the Bosnian Army (the Federation). Few made it to safety, however. They were killed in the woods, and those who 
went to Potocari perished in the massacre. The small town of Srebrenica has been Serb controlled territory (Republika Srpska) since the Dayton Peace Agreement of 1995. The ethnic cleansing has proven to be effective; few Muslims have returned. It is a ghostly place, empty, bearing numerous signs of war, and a lieu de memoire for the Bosnian genocide. Only since 2001 have Muslims been allowed to return, yet very few can or want to. Nevertheless, more and more have no other choice than "resettlement," as it is known in official UN jargon. Srebrenica is rife with bad memories and still feels unsafe. The poverty-stricken women living in refugee camps have few alternatives, though. Euphemistically called "collective centers," the camps are a no man's land where people live destitute lives amid stench and mud. There is no hope for a future there. Recently, some women have been "resettled," but many of them have ended up living in hostile surroundings. In short, most of the women of Srebrenica are living miserable lives, mourning the loss of their loved ones.

Ten years after the end of the civil war, its history is being written, and we can see the beginnings of a memorial culture in which the "real facts of war," such as the defense of Sarajevo, the role of political leaders, the military strategies, and the reaction of the international community, form part of the founding myths of a new nation. The genocide is part of that memory, but it is a memory shaped by many accusations and unpleasant, conflicting views of what happened. The systematic killing of more than 7,000 Muslim men is part of a history of international betrayal. Indeed, Srebrenica was a factor in the negotiations between the international community and representatives of the Bosnian government led by the then president, Alija Izetbegovic, who was eager to lift the siege of Sarajevo. It is generally assumed that the siege of Sarajevo was lifted in exchange for the fall of the enclave. Clearly, then, Srebrenica is also the story of Bosnian betrayal. Despite the many reports and analyses devoted to this episode, no one has ever clarified how it could happen. The struggle for control of the memorial culture is focused on the resulting contradictions. This is a political struggle, however. Academic debate on the history of the betrayal and genocide has yet to begin. The various reports and analyses through which the political debate is conducted often emanate from research teams of the nations and armies involved. They contrast sharply with the memories of the genocide survivors, who are rarely mentioned in these reports (only one book on this subject has been published, in French: Collectif L'Esprit des Peninsules 2000).

\section{Interviewing the Women, the Survivors}

In the autumn of 2002, I visited the enclave of Srebrenica for the first time to assess the feasibility of conducting an interview project with Bosnian women about the massacres and their sad aftermath. Although I was warned that it would be an uphill struggle, my proposal met with a great deal of cooperation. I also visited Bosnia as a member of a Dutch delegation attending the inauguration of the 
Srebrenica monument (cemetery) on 20 September 2003. During this ceremony, 25,000 people, mostly women, crowded on the hill behind the cemetery. We wept, visitors and Bosnians alike, as we buried the 100 identified men under the imposed security of the many military forces still present, notably the US Air Force. Some onlookers wept for the shame of the international community; some, like the Bosnian warlord in front of me, wept for the defeat. Most wept for lost loved ones, and others wept tears of fury for not knowing what had happened to them, for the emptiness of their lives since 1995 and the impossibility of returning to normal life when the scene of the crime is one's own home. The day before, we had visited one of the gravesites with Hatidzja, who spoke softly of her husband, brothers, and father. At the ceremony, I tried to listen to "Srebrenica Inferno," a requiem, submerging myself in the beauty of the music. I tried to repress the thought that boys like the one singing before us would have been killed simply for being male, over a certain age, and a Muslim.

Once I began work on the interviews and listened to the many painful and agonizing accounts, strange stories started turning up in my dreams, disturbing every notion of good and evil. Although I communicated through a translator on my numerous trips and therefore could not speak with the women directly, I was presented with moving accounts of flight, anxiety, fear, and life in the camps. I am quite sure that there was, and still is, a basic feeling of trust and understanding between the Bosnian women and myself. Thus, I slowly learned to communicate with them, even before I started to learn their language.

I struggle with language, a problem I try to solve by transcripts in Bosnian and literal translation of every transcript. I work with translators who want to join the project and who are not scared to listen to the atrocious stories. They are Bosnian women who often work in nongovernment organizations (NGOs), although they are used to witnessing suffering, they have difficult moments. I have learned that the emotional involvement and softness are the most important requirements for a translated interview. Nevertheless, translated interviews do not allow for the secondary analysis of interviews I am used to making. I try to understand the original written Bosnian transcript and follow the flow of the interview.

As part of my project on the life stories of the women of Srebrenica, I conducted interviews in Srebrenica, the surrounding villages, the camps ("collective centers"), and in Sarajevo and its suburbs, where refugees have found shelter. According to some estimates, 6,000 people have not found their way back home. They want to know why their husbands, fathers, and sons were killed; they want to know the history of what happened elsewhere and internationally and wonder whether there were negotiations. In short, they want to preserve the memory of what so many seem to want to forget.

These women have managed to become a voice in Bosnian politics, but that does not mean that their society cares about them, or that others in Bosnia really listen to their memories and stories. They get a lot of internal coverage. Although thinking about Srebrenica is painful, their government wants the book to be 
closed, as does the Dutch government, which, despite lengthy discussions, has abruptly ended all negotiation regarding financial help for my project. The government in The Hague has, in many ways, acted negatively and has decided it will deal with the women only through the courts, refusing to consider any claims for financial compensation. The women are indeed preparing lawsuits and claims for reparations from their government, the Republika Srpska, The Netherlands, and the UN. They appear in public, but in the end, they are viewed by these institutions merely as peasant women, the lowliest immigrants in Sarajevo and the regional capital Tuzla.

They show us they exist and have something important to tell. They contrast the many reports written on Srebrenica until now, which hardly mention them. It is as if history of genocide can be written without the story of the victim. The many national reports prepared by the countries involved and the new memorial literature of Bosnia all neglect their suffering. When the women are mentioned, it is like an invocation of their existence, which does not imply that they are seen as human beings with a past and a future. When they talk to me, of course, fury about the betrayal by the world is a possible meta-narrative, but the narratives are usually more complicated. Because they oppose any (semi-) official story that denies any other outcome of the events and resist the fact that no one answers the question why there was no other outcome, their stories seem to be stories outside of order: often chaotic, as traumatized stories tend to be. These women share the wish to explain that they were left alone and betrayed by the world. That no one seems to care. They are also stories that, in my view, ask the world questions about moral accountability. Furthermore, the world closes its ears to such a painful suggestion. They have been seen as wicked, comparable with the Mothers of the Plaza de Mayo in Buenos Aires. They have blocked the highway to the coast, and they are not easy to deal with.

The women recount the arrival of the Serb soldiers (known as the Chetniks), the disruption of previously good relations between the ethnic groups and the mass murder. They also describe how they have tried to give meaning to what happened to them, how they have resumed their lives, and how they have attempted to incorporate their experiences into their life stories. These are sometimes traumatic fragments that reflect the women's truth about their subjective experience (see also BenEzer 1996, 2002; Rogers et al. 2005; Weine 1999; Felman and Laub 1992). "Truth" in this case is consistent with what the psychoanalyst Shoshanah Felman calls a truth more profound than legal truth - which she saw as institutionalized and culturally channeled - and more complex than judgment and ordeal (Felman 1995, p. 16). The stories show us the microhistories of a genocide; they are diverse and profoundly human. In this paper, I would like to present Sabaheta's story to show how moving such a story can be and how convincingly it makes the case that history should include witness accounts: A type of account very different from that regularly given at the International Tribunal in The Hague (Amadiume, An-Na'im, 2001) or at the Rwanda trials. 


\section{Sabaheta's Story}

We sit with my translator in the office of the "Mothers of the Srebrenica and Zepa Enclaves" in Sarajevo. It is a gray morning. "May the Almighty give me the strength to find the right words." Her face is sad, pale, and full of stress. Her eyes fill with grief. "My name is Sabaheta," she says. "During the fall of Srebrenica, my son, my only son, was captured by Chetniks, and my husband, who fled through the woods, did not reach free territory." This is how she begins on our first meeting. Many more meetings have followed, and we like each other. Sabaheta trusts me, despite our awareness, we have different places in this world, think differently about the past and future of Bosnia. However, I am not a politician, I am critical of the Dutch official attitude, and she knows how much I am at odds with that. She likes it that I listen, and the face of the furious protestor is always soft when she looks at me. I see her grief; I wish I could help her. I cherish the friendship that is there despite the fact that I do not always agree with the politics of the group she belongs to. I feel at ease with her, she can trust me.

Her voice is shrill, her emotions barely under control: "All my joys and my happiness up to then have been replaced by pain and sorrow for my son and my husband. All my life up to then, my whole life since birth, was simply unmade when my son was captured, and my husband did not escape." I look at this woman before me who is forcing herself to relate her experience of the worst genocide in Europe since the Second World War. Images of the 3 days she spent in the compound are clearly before her eyes as she speaks. She relates how the men were separated from the women to be killed. She tells me how, after days of suffering, the women were deported to various refugee camps in the Federal Republic of Bosnia. How she had wanted to save her little boy who was only 12 years old.

The happiness of her normal family life was disrupted in 1992 when she first experienced the ethnic aggression in Bosnia Herzegovina. That year, Srebrenica was conquered by the Serb Army for the first time. She relates: "There was commotion in my town, in Srebrenica." There was word on the street of looming clashes between Serbs and Muslims, but she and her husband could not believe it. She never dreamed that her neighbors would harm her. "So I stayed in Srebrenica with my husband and my son, thinking that nothing terrible could happen. But on April 18, 1992, when I got up and went out onto the balcony of my flat, I saw all my Serb neighbors in a row in the street, armed and in uniforms." Even then she was not afraid. After all, they were familiar faces.

However, in fact, Arkan and his feared Serb paratroupers had entered the town, and the throat-cutting and killing started immediately. Arkan's troops were well known for the atrocities they had committed in many places in Bosnia; they were recently in the news for the film that has recently emerged, in which we see the murder of some young men in Srebrenica. If Arkan entered a town or village, the Muslim population would usually be slaughtered. Arkan became a symbol of Serb violence. The soldiers set fire to houses and people and slaughtered women, men, 
and children. Sabaheta and her husband waited to be killed, but it did not happen. They fled to the forest, where they hid with a few hundred more Muslims for several weeks. The Serbs were routed by the Bosnian Army later that April, and all who had fled to the woods returned home. However, the surrounding countryside was not liberated, and the town was filled with thousands of people seeking shelter. An "ethnic cleansing" campaign was going on everywhere outside of Srebrenica, and the town seemed like a last refuge. "There was no way out. The Chetniks immediately started shelling and bombing, claiming the first victims. We were not safe any longer, either outside in the streets or inside the flats and houses. The town was on fire." From then on, the inhabitants of Srebrenica were shelled and hunted by snipers. They became increasingly isolated from the rest of the world because the enemy had cut off food supplies. However, the worst was yet to come, as even more people tried to find refuge in Srebrenica, and the town became overcrowded. At one stage, 45,000 people were living there, tripling the prewar population. Nevertheless, they felt secure in a town that had been declared a safe haven by the UN, first under the protection of Canadian and French troops and later the Dutch Army.

Sabaheta disliked the Dutch and mentioned an incident that illustrates how the Dutch treated the starving Bosnian population as subhuman.

The Dutch soldiers behaved badly during their mandate.... They behaved in a generally inhumane way. They provoked children, they provoked young women. They made fun of them. I shall give you an example. They had an observation point near Vezionica [an embroidery plant] where they had a base. A Dutch soldier would sit there, and the children would look at him - they did not know any longer what a candy bar was, they had forgotten. They had no fruit, no juice, nothing. He would sit there and drink CocaCola from a can, enjoying the drink, laughing. The poor children would look at him. $\mathrm{He}$ would drink some Coca-Cola and throw the rest to the kids, or he would throw one piece of candy, or he would take one bite from an apple and throw what was left to the children. As if they were animals, not human beings.

She felt humiliated, a feeling that surfaced in nearly every interview: "The Dutch despised the Bosniaks, as the Muslims were called." However, there is an ambivalence to her story. She was certain she would be protected, so she still paid heed to the Dutch when she felt she was in danger.

Dislike of the Dutch Army has become a commonplace way of expressing rage among certain groups of women, but it is not merely a topos. Although the criminal behavior of the troops is at times exaggerated, the stories about violent behavior and even rape by the protectors are too numerous to ignore. These accounts must be taken seriously, although other women recount stories of genuine help by Dutchbat (as the Dutch troops were called), and still others see that their fate was in the hands of people much further away.

According to Sabaheta, the Dutch soldiers left their posts when the final offensive began. Like many others, Sabaheta went to the UN compound in Potocari, $5 \mathrm{~km}$ from Srebrenica. Her husband, like many of the able-bodied men, decided to escape through the woods to Federation territory. They hoped they would meet again. She 
did not believe that she and her 12-year-old son could make it through the woods, so the compound was her only alternative. After 3 days of waiting there, women and men were separated. She recalls that the Dutch soldiers did nothing to prevent this separation and allowed a cordon to be set up, through which the women had to pass. It was here that Serbian soldiers ordered her son to go to the other side and took her child away. "They captured my son, though I tried to fight the Chetniks. But I failed. They got me in the truck ... after that, I tried to commit suicide." Sabaheta was transported out of Srebrenica in a truck. I asked her how. She answered:

All the time I have tried to avoid talking about that.... It is very difficult to talk about it, and I would never be able to tell you all I went through. I can tell you only a part of the story. On July 11, at around five o'clock in the afternoon, I arrived with my son in Potocari. There were already many people there, refugees from Srebrenica who had all come in the same way. My son and I slept in the open air on the nights of the eleventh and twelfth. We had tried to enter the UN compound, where the wire fence had been cut to let everyone in, but there was no place left. I was already worried about the future of my child. On the twelfth of July, at ten o'clock, we were handed over to the Chetniks.

The Chetniks immediately entered [the compound] and started walking around saying to the men: "you, you, and you." And they took them away, allegedly to be interrogated, after which, we were told, they would be brought back. When the Chetniks came inside, walking among us, my son was a bit afraid. And I was terribly afraid, but I managed not to show it to my child. My mother was with me. She is still alive and living with me now. We were together at Potocari. I was sitting there and thinking: what can I do with the child? I had the feeling that I would not manage to get him through this. When the deportations started, we heard rumors that further down they were separating male children and men regardless of age. It was a large area, a complex of factories, an industrial zone, now filled with women, children and men expelled from Srebrenica, all waiting for deportation. In the distance, among the Serbs, I noticed S.P. and M.G. The first was my next-door neighbor. He was with his son Pedrag, who was the same age as my son. I decided to ask them for protection.

Here, again, she trusts old ties and familiar faces.

I tried to push my way through the crowd. But suddenly I had an urge to return to my mother and son. The urge was stronger than me so I had to return. I came back to the place where I had left them. My mother was crying, but my Riki was not there.

He had been taken away. Sabaheta rushed to the Chetniks, some of whom she knew, and her fury forced them to give him back.

They stayed there another night, "a terrible, awful night filled with cries, full of horror. You could hear someone crying, and all of us, maybe 15,000 people, we all got up and cried. Can you imagine 15,000 or 16,000 people weeping and crying and nobody hearing! I think it could have been heard in half of Serbia. And the world did not know what was happening?" She suggested suicide to her mother and her son, but he refused. Then came the last morning. Together, they went to the trucks and buses, which had arrived with the Serbian Army that night. They did not know where they would go; all they knew was that they would be evacuated. 
I moved slowly, arm in arm with my son. Others were going two by two. When we came to the Chetniks, they immediately told my son to go to the right, and I was to go straight on. We did not listen but moved straight ahead. But that was not allowed. They immediately came to us and said my son should go to the right and that I should go straight on.

Riki looked at her, and she looked at him for the last time. "Large tears were on his cheeks, he embraced me and kissed me and said 'Please, mother, go.' They grabbed him. I did not want to go. I knelt down and told them 'Please kill me, kill me, you've taken my only child. I do not want to go anywhere. Kill me, and that will be the end for us." She believed she would be killed and was happy. However, she was thrown into the truck and lost consciousness.

Sabaheta is now glad that she failed to commit suicide: "Thank God, I did not manage it. Because if I had managed to kill myself then, who would be looking for my son and my husband?" She says no one answers her questions about what exactly happened to them. As a religious Muslim, it is her duty to bury them. She accuses the world, which includes the French, the Dutch, and the UN, of wanting to forget these events. Her voice is filled with rage:

If in one day thousands of children are taken away from their mothers, if so many men and women disappear in the woods and nobody knows anything about it - well, I cannot understand that. I have come to realize that everyone wants to forget the genocide at Srebrenica. And that has given me even more strength to discover everything that occurred in Srebrenica and to find out what happened. I cannot forget my son and my husband and I want to know what happened to them.

Many of the people Sabaheta trusted failed to help her, including her neighbors and her supposed protectors, the Dutch. Now, she is furious and she is taking action. Many Bosnian women, like Sabaheta are speaking out, showing that the war was also a war against women, and that "ethnic cleansing" and "genocide" are terms that mask gendered acts of violence. "Ethnic cleansing" means death, but to women, it also means rape by soldiers serving the "superior" race. It is not gang rape - which happens in every civil war - but rape intended to engender another race through the women of the subjugated enemy. The "superior" race thereby destroys the last shred of the women's dignity, reducing the women to the level of livestock. In I Begged Them to Kill Me, published by the Association of Former Prison Camp Inmates, women speak up about rape. The focus on the staggering number of rape victims (estimates are well in excess of 200,000) tends to make us forget how many widows have been left behind in camps and suburbs practically devoid of men. This is the type of sexual violence that is particularly pertinent in the case of Srebrenica's women: being left without men, except for the very young and the very old. A whole generation of women has to make do without men. More witness accounts of the ordeal by Bosnian women have recently been published (Hunt 2005). My repeated stays in Bosnia have made me realize that for the women, not knowing how their husbands died, is particularly hard. I have heard many stories of women who are still waiting. Only when DNA tests have 
revealed the identities of the bodies in the mass graves do they begin to believe that their husbands and sons will not return. They are all mourning the loss of their men and have been forced to build new lives, though they can barely manage. However, worst of all, they have been silenced by their own government and the international community. They have been portrayed as those "Mad mothers of Srebrenica," who have had a history of clashes with the police since 1996 and once even blocked the road to the coast (2000). One woman told me about a protest in 1996 in Tuzla, where they were told they were wild animals. All they had done was ask for information about their men at the Red Cross office.

\section{Srebrenica and the Dutch}

Shortly after the fall of Srebrenica, the Dutch government asked The Netherlands Institute of War Documentation (NIOD 2002) to conduct a historical inquiry to gain an understanding of what had happened. They were to investigate questions such as: Who was responsible for the failure to protect the people? And what was the role and responsibility of the Dutch government? Of course, there were many more questions that could be asked, but the political discussion was polarized between accusations and the official answer, which maintained that the events of 1995 could not have been avoided. The inquiry took years and was finally completed in 2002. However, the report was considered so vague in its final analysis that parliament launched its own inquiry. Many viewed the NIOD report as a sophisticated whitewash, despite its huge size, official status, and the long time taken to write it. It was immediately criticized by the public, and it led to a ministerial crisis, resulting in the resignation of the Dutch prime minister and another minister in his cabinet.

The Bosnian women walked out during the presentation of the report. Although officials claimed that the women were manipulated by one of the NGOs active in the political debate, I am convinced that they felt the Dutch were obsessed with their own moral and political predicament.

The parliamentary inquiry clarified, to a greater extent, what had gone wrong within the Dutch command. Responsibility for the events was accepted in a general sense, although the question of whether the Srebrenica crisis could have been handled differently was not really addressed. The same is true of the French report, the report by the Republika Srpska in 2004, and other inquiries to date. Some Dutch historians have investigated in major academic journals how politics and history have merged in the "semiofficial" historical study of the Dutch role in the massacre (BMGN 2003; TvG 2003). Surprisingly, the absence of the survivors' voices is not mentioned anywhere in this critique. According to many historians in the international arena, the real academic research - that is to say historical work not hindered by politics - has yet to begin. It is also imperative that historians and social scientists work together in an international project that tries to overcome the political agenda (see Ingrao and Emmert 2006). 


\section{Official Stories vs Survivors' Stories}

For posterity's sake, it is vital to record the stories of survivors of the 1995 massacre (Smith and Schaffer 2004). We cannot predict what these as yet unheard voices will add to our historical understanding of Srebrenica, but one can safely assume that listening to them will alter the historical narrative of that fateful chapter. In addition, quite apart from this, I believe that the survivors, the mothers, wives, and daughters of the victims, have a right to tell their stories (Minow 2002). It has been the role of the historian to document the atrocities of genocide (Power 2002) as was for instance the case many years after the Armenian genocide (Akcam 2006; Miller and Miller 1993; Balakian 2003). Such documentation activities occupy whole departments of Holocaust and Genocide Studies. Communities need to speak to come to terms with what has happened; to tell the story is part of survival.

It typically takes a long time before the stories of victims are written down. The best-known example of this is the Shoah/Holocaust; it was decades before the Jews persecuted in the Second World War were granted a public voice. For a long time after such a tragedy, it is too difficult to listen to such stories (Leydesdorff 2004). They come too close. They stir up the listener's feelings of guilt that what happened was not prevented. They are frightening. We know that this empty blackboard is the background against which people stage themselves in the story, using many registers to make themselves acceptable. The most acceptable is the tale of the victim's suffering not the anger of a woman at a demonstration, her fury, or protest. These women are dismissed as hysterical and unreasonable. However, they are angry. They refuse to speak in the register of victimhood. Through demonstrations and violent protest, they show that they want to know what happened. They aim to demonstrate their conviction that what happened could have been avoided and their distrust of every official suggestion of inevitability. They also show anger at being forced to live as refugees. It is a pattern similar to that found among the women of Rwanda.

Shoshanna Felman, who has worked extensively with the stories of traumatized people, has rightly pointed out that, theoretically, there are as many stories about trauma as there are identities dealing with it. There is, in the field of oral history, an entire literature on stories of trauma that mainly points out the difficulty of interviewing a traumatized person. Trauma narratives are always highly personal accounts of survival; they often contain several messages and rely heavily on genres (Dante, Dostoyevsky). An argument be made that these testimonies valorize the notion of silence, because it is the impossibility of writing on the basis of silence that originally gave rise to testimonial literature (Crownshaw and Leydesdorff 2005). Felman and Laub (1992: 57) have argued that trauma has not truly been witnessed until the process of testimony takes place, thus necessitating the eyewitness account. The idea that the trauma story is not a straightforward referential narrative has been discussed in much of the literature. We know that 
survivors can give meaning, but that this can only be done in a context that allows them to speak. Young (1988: 22) has argued that the witness can act and master agency by a "configuration" of the event. That is a keen observation because it is precisely what happens during the interviews; the women feel they are giving a meaning to their rage while talking to me. The life stories are, in a way, also testimonies.

In my experience, women who give testimonies are trying to give meaning to their stories, placing their account in a larger context. Fury about betrayal is one possibility, but the narratives are usually more complicated than that. Because they oppose any (semi-) official story and defy the fact that they have been muted, they seem anarchic, often chaotic, as trauma stories tend to be. These women seem to share the desire to explain that they have been abandoned and betrayed by the world and that no one seems to care. In my view, they are also stories that pose questions about moral accountability on the basis of a different kind of knowledge.

In that sense, Sabaheta's story is one of these new truths; her narrative is subjective (as it should be), a lament as she tells it. She says she is deeply religious because it is her only remaining resource, and she assumes that I understand this. It is the truth of the victim trying to escape her symbolic boundaries. It is an ambivalent truth of betrayal, of being forsaken by everyone, and also of being silenced. It is the story of someone who has trusted her neighbors and her 'protectors' and who has every reason to be furious. In short, it is a story that is hard to listen to. I strongly believe that no history can be written without knowing and accounting for such historical 'facts' at an empirical and a theoretical level.

\section{Appendix}

The literature covering the events at Srebrenica is extensive, and I mention only a few reports here. For the women I interviewed, the most important report is Hasan Nuhanovic's The role of International Factors in Srebrenica, Sarajevo 2002. It has been admitted as evidence in a civil lawsuit and in trials at the International Criminal Tribunal for the Former Yugoslavia. This English translation of it has not been published.

NIOD, Srebrenica, een 'veilig gebied'. Reconstructie, achtergronden, gevolgen en analyses van de val van een Safe Area (Boom, Amsterdam, 2002).

Rapport d'information de MM. René André et Francois Lamy, no. 3413, deposé le 22 novembre 2001, en application de l'article 145 du réglement (l'Assemblée Nationale, Paris 2002).

Republika Serbska, The events in and around Srebrenica between 10th and 19th July 1995, Banja Luka June 2004. With Appendix, October 2004. 


\section{References}

Akcam, T. 2006. A Shameful Act: The Armenian Genocide and the Question of Turkish Responsibility. New York: Metropolitan Books.

Amadiume, A. and An-Na'im, A. 2001.The Politics of Memory. London, New York.

Balakian, P. 2003. The Burning Tigris: The Armenian Genocide and America's Response. New York.

BenEzer, G. 2005 (reprint of 1996). "Trauma Signals in Life Stories," In K. Lacy Rogers and S. Leydesdorff, Life Stories of Survivors, Trauma. New Brunswick. 29-45.

BenEzer, G. 2002. The Ethiopian Jewish Exodus, Narratives of the Migration Journey to Israel 1977-1985. London, New York.

Bijdragen en Mededelingen betreffende de Geschiedenis der Nederlanden (BMGN), vol. 118, 3, 2003, pp. 293-356.

Cecik, S. et al. 2001. Genocide in Srebrenica, United Nationas "Safe Area" in July 1995. Sarajevo.

Collectif L'Esprit des Peninsules. 2000. Srebrenica, l'ete d'une agonie. Paris.

Crownshaw, R. and Leydesdorff, S. 2005. On Silence and the Words of the Victims." Introduction to the reprint of Passerini, L. 2005. Memory of Totalitarianism. New Brunswick. VII-XIII.

De Barros-Duchene, L. 1997. Srebrenica, Histoire d'une crime international. Paris.

Felman, S. and Laub, S. 1992. Testimony: Crises of Witnessing in Literature, Psychoanalysis, and History. New York, London.

Felman, S. 1995. "Education in Crisis, or the Vicissitudes of Teaching." In C. Caruth (ed.), Trauma, Explorations in Memory. Baltimore.

Honig, J.W. and Both, N. 1996. Srebrenica: Record of a War Crime. London.

Hunt, S. 2005. This was not Our War: Bosnian Women Reclaiming the Peace. Durham.

Ingrao, Ch. and Emmert, Th. (eds.). 2006. Confronting the Yugoslav Controversies: A Scholars' Initiative. West Lafayette, IN: Purdue University Press.

Leydesdorff, S. 2004. "The State within the State: An artisan remembers his identity in Mauthausen." In: Studies on the audio-visual testimony of victims of Nazi crimes and genocides, No. X. Brussels. 103-117.

Miller, D.E. and Miller, L.T. 1993. Survivors: An oral history of the Armenian Genocide. Berkeley.

Minow, M. 2002. Breaking the Cycles of Hatred, Memory, Law and Repair. Princeton.

Power, S. 2002. "A Problem from Hell:" America and the Age of Genocide. New York.

Rhode, P. 1997. "Endgame Srebrenica." The Betrayal and Fall of Srebrenica: Europe's Worst Massacre since World War II. Bolder.

Rogers, K. and Leydesdorff, S. 2005 (reprint of 1996). Life Stories of Survivors, Trauma. New Brunswick. 29-45.

Silber, L. and Little, A. 1997. Yugoslavia: Death of a Nation. Harmonsdsworth: Penguin Books.

Smith, S. and Schaffer, K. 2004. Human Rights and Narrated Lives, The Ethics of Recognition. New York.

Tijdschrift voor Geschiedenis (TVG), Het drama Srebrenica, Geschiedtheoretische beschouwingen over het NIOD-rapport, vol. CXVI, 2, 2003, pp. 190-327.

Weine, S. 1999. When History is a Nightmare, Lives and Memories of Ethnic Cleansing in Bosnia Herzegovina. New Brunswick, London.

Young, J.E. 1988. Writing and Rewriting the Holocaust. Bloomington: Indiana University Press. 